\title{
PENGARUH MODEL KOOPERATIF TIPE STUDENT TEAM ACHIEVEMET DIVISION (STAD) TERHADAP MOTIVASI DAN HASIL BELAJAR MATA PELAJARAN BIOLOGI SISWA KELAS X SMA NEGERI 1 HU,U
}

\author{
Susi Susanti ${ }^{1}$, Fahruddin ${ }^{2}$, Olahairullah $^{3}$ Muhammad Iqbal $^{4}$ Ferawati $^{5}$ \\ ${ }^{1}$ Mahasiswa Program Studi Pendidikan Biologi, STKIP Bima \\ 2,3,4,5Dosen Program Studi Pendidikan Biologi, STKIP Bima. Jalan Piere Tendean Kel. Mande Tel. \\ Fax (0374) 42801, Bima 84191, Indonesia. \\ Email: (bangfenmbozo@gmail.com)
}

\begin{abstract}
Abstrak
Penelitian ini bertujuan Untuk mengetahui pengaruh model pembelajaran kooperatif tipe STAD terhadap motivasi belajar dan hasil belajar peserta didik kelas X di SMA Negeri 1 Hu'u. Jenis penelitia quasi eksperimen. Populasi adalah peserta didik kelas X SMA Negeri $1 \mathrm{Hu} u$ tahun ajaran 2019/2020 sebanyak 5 kelas berjumlah 149 siswa, pemilihan sampel penelitian menggunakan tehnik cluster random sampiling, kelas X IPA ${ }^{1}$ yang dibelajarkan dengan menggunakan model pembelajaran langsung (direct intruction) dengan jumlah 27 siswa dan kelas X IPA ${ }^{2}$ yang dibelajarkan dengan menggunakan model pembelajaran kooperatif tipe STAD dengan jumlah siswa sebanyak 27. Instrumen dalam penelitian ini yaitu angket motivasi belajar dan soal pilihan ganda 25 soal. Analisis data menggunakan uji-t. Hasil analisis datan menggunakan rumus $t$ test diperoleh nilai sebesar 27,0 > 1,674 dengan nilai signifikasi 0,05 maka dapat disimpulkan bahwa terdapat pengaruh model pembelajaran STAD terhadap motivasi dan hasil belajar peserta didik SMA Negeri 1 Hu, u tahun pelajaran 2019/2020.
\end{abstract}

Kata kunci: Kooperatif Tipe STAD, Motivasi Belajar, Hasil Belajar.

\section{PENDAHULUAN}

Pendidikan adalah usaha sadar dan terencana dalam berbagai dimensi kehidupan manusia untuk menciptakan sumber daya manusia yang berkualitas (Kartimi.dkk, 2014). Upaya untuk meningkatkan kualitas pendidikan adalah dengan mengoptimalkan proses pemebelajaran.Salah satu cara mengaktifkan siswa dalam proses pembelajaran yaitu guru harus mampu memilih metode pembelajaran yang tepat.

Pembelajaran sains khususnya biologi berkaitan dengan proses keilmuan untuk memperoleh pengetahuan tentang alam/lingkungan secara sistem matis, sehingga ilmu ini bukan hanya penguasan kumpulan pengetahuan yang berupa faktorfaktor, konsep-konsep,atau prinsip-prinsip saja tetapi juga merupakan suatu proses penemuan (Suraida, 2013). Oleh karena itu, proses pemebelajaran biologi tidak terbatas dengan model pembelajaran yang konvensional saja seperti ceramah, diskusi, tanya jawab atau pemeberian catatan-catatan pembelajaran. Trianto (2010) menyatakan bahwa masalah utama pendidikan formal (sekolah) saat ini rendahnya hasil belajar 
siswa akibat dari penerapan pembelajaran kovensional di sekolah.

Hal ini dikarenakan dalam pelaksaan pembelajran konvensional lebih didominasi oleh guru dan kurang memberikan akses bagi siswa untuk berkembang secara mandiri. Salah satu contoh sekolah yang menerapkan pembelajaran kovensional adalah di SMA Negeri $1 \mathrm{Hu}$ 'u.

Bedasarkan hasil obervasi dan wawancara dengan guru mata pelajaran biologi kelas X SMA Negeri 1 Hu'u tahun ajaran 2019/2020 mengenai pembelajaran di sekolah menujukan bahwa pada proses pembelajaran biologi guru sering menggunakan metode dan strategis pembelajaran yang kurang kolaboratif atau metode yang menoton sehingga timbul kebosanan pada siswa yang menyebabkan turunnya nilai hasil belajar siswa. Proses pemebelajaran tersebut cenderung di dominasi oleh guru dan kurang memberikan kesempatan bagi siswa dalam menggembangkan pengetahuan dan penemuan masalah secara mendiri serta pemecahan masalah kompleks yang ada dalam materi pembelajaran. Adapun beberapa langkah metode yang menimbulkan kebosanan terhadap siswa tersebut antara lain yaitu: 1. Guru masih kurang melakukan kuis atau memberi pertanyaan kepada siswa, 2.
Guru tidak memberikan penghargaan (rewards) kepada kelompok yang memiliki skor tertinggi dalam diskusi kelompok, 3. Guru kurang melakukan evaluasi sehingga tingkat perkembangan pemahaman peserta didik belum diketahui terhadap materi yang telah guru ajarkan.

Pembelajaran dominan tersebut menyebabkan rendahnya motivasi belajar siswa. Rendahnya motivasi siswa di tunjukkan pada: 1) siswa cenderung pasif,karena siswa yang hanya terbatas pada mendengarkan, mencatat, dan menghafal pengetahuan yang di sampaikan oleh guru, 2) siswa kesulitan mengembangkan pengetahuan 3) siswa kurang berani menyampaikan pendapat, ide dan gagasanya di depan kelas. Hal tersebut berkebalikan dengan uraian yang dikemukakan oleh Uno (2007) m engenai dorongan untuk melakukan kegiatan belajar yang disebut sebagai motivasi belajar. Hasil observasi yang terlihat menandakan dorongan untuk belajar siswa rendah, sehingga dapat dikatakan motivasi belajar siswa masih rendah. Dilihat dari hasil wawancara dengan guru mata pelajaran rendahnya motivasi belajar siswa dapat berdampak pada hasil belajar siswa hal ini dapat dilihat dari hasil observasi ulangan harian biologi tahun 2018/2019 materi virus siswa kelas $X$ yang kurang memuaskan atau belum tuntas. 
Materi virus merupakan materi pelajaran biologi dengan obyek yang memiliki sifat yang sangat beragam, baik ditinjau dari ukuran (mikroskopis), keamanan (virus yang bersifat patogen) dan bahasa (bahasa latin dalam nama ilmiah). Menurut Guru biologi SMA Negeri 1 Hu'u, banyak kemungkinan yang menyebabkan siswa mengalami kesulitan dalam memahami, mengaplikasikan dan menvisualisasikan konsep dari virus tersebut Sudarisman (2015)

Menanggapi permasalahan tersebut, perlu di adakan suatu inovasi baru dalam pemilihan model pembelajaran yang sesuai dengan karakteristik materi virus sebagai upaya peningkatan motivasi dan hasil belajar siswa salah satunya dengan menggunakan model pembelajaran kooperatif tipe Student Team Achievemen Division (STAD).

Model pemebelajaran tipe Student Team Achievemen Division (STAD) dirasa tepat untuk diterapkan pada materi pokok virus hal ini dikarenakan model pembelajaran tipe STAD mampu melibatkan siswa untuk bekerja sama secara kolaborasi dalam sebuah kelompok untuk mencapai kompetensi dalam konsep virus yang sesuai dengan indikator pemeblajaran yang ditentukan. Kegiatankegiatan yang ada dalam model pembelajaran STAD meliputi pembagian kelompok secara heterogen, bekerja dalam tim, evaluasi kelompok dan kuis individu dan pengghargaan tim di harapkan dapat memudahkan siswa untuk memahami dan menfisualisasikan konsep virus serta saling membantu memecahkan masalah-masalah komples jika mereka saling berdiskusi dengan temannya (Triyanto, 2010). Selain itu, dengan penerapan model pembelajaran tipe STAD dapat menjadikan siswa berpartisipasi penuh, aktif, produktif dan kreatif dalam proses pembelajaran.

Slavin (2005) menyatakan bahwa STAD siswa ditepatkan dalam tim belajar yang terdiri atas 4 orang yang berbeda-beda tingkat kemampuan, jenis kelamin dan latar belakang etniknya. Proses pembelajaran di awali dengan guru menyampaikan tujuan dan motivasi pembelajaran, lalu siswa bekerja dalam tim. Selanjutnya, semua siswa mengerjakan kuis mengenai materi secara individu. Skor kuis individu kemudian dijumlahkan dengan skor kelompok untuk memperoleh skor tim dan tim yang berhasil memenuhi kriteria tertentu akan mendapatkan sertifikat atau penghargaan lainnya. Model pembelajaran kooperatif tipe Student Team Achievemen Division (STAD) ini diharapkan dapat membantu siswa dalam memahami konsep-konsep dasar esensial sebagai landasan dalam mengembangkan pengetahuan, perilaku dan sikap siswa agar 
pemebelajaran pada materi virus lebih menarik dan bermakna (Rahmat, 2010).

Kegiatan yang dilakukan guru dengan memodifikasi model pembelajaran merupakan upaya guru untuk menarik perhatian siswa sehingga menciptakan motivasi belajar dan mempengaruhi hasil belajar siswa. Hal ini sejalan dengan pendapat Hamalik (2008) yang menyatakan bahwa peningkatan motivasi belajar erat kaitannya dengan peningkatan hasil belajar siswa yang dapat dilakukan dengan perencaan pembelajaran yang tepat dengan mengarahkan motivasi belajar kearah kegiatan-kegiat kreatif.

\section{METODE}

Pendekatan yang digunakan dalam penelitaian ini adalah pendekatan kuantitatif dan kualitatif dengan jenis penelitian quasi eksperimen. Terkait pendekatan penelitian yang menggunakan kuantitatif, maka penelitian ini mencakup setiap jenis penelitian yang didasarkan atas perhitungan skor/nilai, rata-rata, chi kuadrat, dan perhitungan statistik lainnya. Sedangkan terkait jenis penelitaian eksperimen dapat diartikan sebagai metode penelitia yang digunakan untuk mencari pengaruh perlakuan tertentu terhadap yang lain dalam kondisi yang terkendalikan. Hal ini sesuai dengan konsep dasar penelitian eksperimen seperti yang dijelaskan bahwa penelitian eksperimen harus mengungkapkan hubungan sebab-akibat antar variabel, dan menguji pengaruh dua variable. Penelitian ini difokuskan pada pengaruh salah satu model pembelajaran kooperatif yaitu tipe STAD dalam pembelajaran dikelas. Maka penelitian ini akan menguji pengaruh model pembelajaran kooperatif tipe STAD terhadap motivasi belajar dan hasil belajar Biologi SMA Negeri $1 \mathrm{Hu}, \mathrm{u}$.

Populasi dari penelitian ini adalah seluruh siswa kelas X SMA Negeri $1 \mathrm{Hu}, \mathrm{u}$ tahun ajaran 2019/2020 yang terdiri dari 5 kelas, dengan jumlah peserta didik sebanyak 149 peserta didik. sampel dengan menggunaan tehnik purposive sampling sampel dalam penelitian ini adalah kelas $\mathrm{X}$ IPA1 sebagai kelas kontrol dengan jumlah 27 orang siswa dan kelas X IPA2 sebagai kelas eksperimen dengan jumlah 27 orang siswa.

Instrumen pada penelitian ini yaitu 25 butir soal tes bentuk pilihan ganda dan angket motivasi belajar.

\section{HASIL DAN PEMBAHASAN}

Untuk mengukur motivasi belajar peserta didik kelas eksperimen dan kelas control maka dibagikan angket motivasi belajar yang sudh di ukur kevalidas dan reabelitasnya. Kemudian data angket motivasi elajr disis oleh responden dan dikumpulkan, dan selanjutnya dilakukan perhitungan data 
angket. Adapun hasil data angket sebagai berikut.

Tabel 1. Nilai Motivasi Belajar Kelas Eksperimen Dan Kelas Kontrol Mata Pelajaran Biologi SMA Negeri $1 \mathrm{Hu}, \mathrm{u}$

\begin{tabular}{|l|l|l|l|l|l|l|l|}
\hline \multicolumn{4}{|l|}{ Eksperimen } & \multicolumn{4}{l|}{ Kontrol } \\
\hline Max & Min & Rerata & SD & Max & Min & Rerata & SD \\
\hline 97 & 78 & 87,00 & 2.350 & 97 & 70 & 81,00 & 2.201 \\
\hline
\end{tabular}

Sumber: Lampiran 02

Bedasarkan data pada tabel diatas nilai motivasi belajar mata pelajaran biologi SMA Negeri $1 \mathrm{Hu}, \mathrm{u}$ di atas menunjukkan bahwa kelas eksperimen memperoleh nilai rata-rata 87 dan nilai rata-rata motivasi kelas kontrol memperoleh nilai rata-rata 70. Data hasil distribusi skor motivasi belajar kelas eksperime dan kelas kontrol dapat dilihat pada tabel 4.2 sebagai beikut :

Tabel 2. Distribusi Skor Nilai Motivasi Belajar Kelas Eksperimen dan Kelas Kontrol Mata Pelajaran Biologi SMA Negeri $1 \mathrm{Hu}, \mathrm{u}$

\begin{tabular}{|c|c|c|c|c|c|}
\hline \multicolumn{4}{|c|}{ Kelas eksperimen } & \multicolumn{2}{l|}{ Kelas control } \\
\hline $\begin{array}{c}\text { Rentang } \\
\text { Nilai }\end{array}$ & Kriteria & Frek & $\begin{array}{c}\text { Porsenta } \\
\text { se (\%) }\end{array}$ & Frek & $\begin{array}{c}\text { Porsentase } \\
(\%)\end{array}$ \\
\hline $80-100$ & $\begin{array}{c}\text { Sangat } \\
\text { baik }\end{array}$ & 26 & $96,29 \%$ & 15 & $55,55 \%$ \\
\hline $70-79$ & Baik & 1 & $37 \%$ & 12 & $44,44 \%$ \\
\hline $50-69$ & Cukup & 0 & - & 0 & - \\
\hline $30-49$ & $\begin{array}{c}\text { Kurang } \\
\text { baik }\end{array}$ & 0 & - & 0 & - \\
\hline \multicolumn{2}{|c|}{ Jumlah siswa } & 27 & $100 \%$ & 27 & $100 \%$ \\
\hline
\end{tabular}

Bedasarkan tabel 2 menunjukkan bahwa motivasi belajar kelas ekspermen diperoleh 26 orang peserta didik yang memiliki motivasi sangat baik dengan presentase 96,29\%, 1 orang peserta didik yang memiliki motivasi baik dengan presentase 37 $\%$, dan motivasi belajar kelas kontrol diperoleh 15 orang peserta didik yang memiliki motivasi sangat baik dengan presentase 55,55\%, 12 orang peserta didik yang memiliki motivasi baik dengan presentase $44,44 \%$.

Hasil analisis statistik berdasarkan skor hasil belajar yang diperoleh peserta didik pada materi virus di kelas ekperimen dan kelas control dapat dilihat pada tabel 3 sebagai berikut:

Tabel 3 Data Hasil Evaluasi Hasil Belajar kelas eksperime dan kelas control

\begin{tabular}{|c|c|c|c|c|}
\hline \multirow{2}{*}{ Statistik } & \multicolumn{2}{|c|}{ Eksperimen } & \multicolumn{2}{c|}{ Kontrol } \\
\cline { 2 - 5 } & Pretest & Posttes & Pretest & Posttest \\
\hline $\begin{array}{c}\text { Nilai } \\
\text { Maks }\end{array}$ & 52 & 92 & 48 & 92 \\
\hline $\begin{array}{c}\text { Nilai } \\
\text { Min }\end{array}$ & 24 & 72 & 16 & 64 \\
\hline $\begin{array}{c}\text { Rata- } \\
\text { Rata }\end{array}$ & 35,85 & 8,3 & 32,6 & 56 \\
\hline SD & 968 & 2.252 & 882 & 1512 \\
\hline
\end{tabular}

Bedasarkan tabel 3 diatas mununjukan nilai hasil belajar peserta didik kelas eksperimen yang memiliki nilai pretest adalah 52 nilai tertingi dan nilai terendah adalah 24 dengan nilai rata-rata 3,58. Sedangkan hasil belajar posttest peserta didik kelas eksperimen menunjukkan nilai tertinggi 92 dan nilai terendah 72 dengan nilai rata-rata 8,3 . Adapun nilai pretest kelas kontrol 
menunjukkan nilai tertinggi 48 dan nilai terendah 16 dengan rata-rata 3,0 untuk nilai posttest kelas control dengan nilai tertinggi 92, dan nilai terendah 64 dengan rata-rata 5,6.

Berdasarkan hasil perhitungan secara statistik nilai $\mathrm{t}_{\text {hitung }}$ sebesar $=27,0$ maka $\mathrm{t}_{\text {tabel }}$ pada taraf signifikan 5\% =1,674. Karena $\mathrm{t}_{\text {hitung }}>\mathrm{t}_{\text {tabel }}$ maka dapat disimpulkan bahwa model pembelajaran kooperatif tipe STAD dapat berpengaruh terhadap motivasi dan hasil belajar siswa mata pelajaran biologi SMA Negeri $1 \mathrm{Hu}$,u tahun pelajaran 2019/2020.

Berdasarkan hasil analisis statistik dengan menggunakan rumus persentase bahwa terdapat pengaruh penerapan model pembelajaran kooperatif tipe STAD terhadap motivasi belajar mata pelajaran biologi peserta didik di SMA Negeri $1 \mathrm{Hu}$, u dengan hasil poresentase sebesar 96,29\% dan berkategori sangat baik. Hal ini dipengaruhi karena model pembelajaran kooperatif tipe STAD memiliki keunggulan yakni menumbuhkan semangat dan motivasi yang tinggi dari belajar berkerja sama dalam kelompok, hal ini didukung oleh penelitian yang dilakukan oleh Risdiyawati (2012), menyatakan bahwa Implementasi Model Pembelajaran Kooperatif Tipe Student Teams Achievement Division (STAD) dapat meningkatkan motivasi belajar Akuntansi peserta didik kelas XI IPS 4 SMA Negeri 1
Imogiri Tahun Ajaran 2011/2012, penelitian selanjutnya dilakukan oleh Imtihan (2013) menunjukkan bahwa motivasi belajar peserta didik yang mengikuti model pembelajaran STAD berbeda secara signifikan dengan peserta didik yang mengikuti pembelajaran konvensional, dan penelitian yang dilakukan Sumargi S.A.K. Dkk (2015) menyatakan bahwa terdapat perbedaan motivasi belajar peserta didik yang mengikuti model pembelajaran koperatif tipe STAD dengan peserta didik yang mengikuti pembelajaran konvensional.

Berdasarkan hasil hitungan dengan menggunakan rumus uji-t diperoleh $\mathrm{T}_{\text {hitung }}>$ $\mathrm{T}_{\text {tabel }}=27,0>1,674$. Sehingga dapat di simpulkan bahwa terdapat pengaruh penerapan model pembelajaran kooperatif tipe STAD terhadap hasil belajar mata pelajaran biologi peserta didik di SMA Negeri $1 \mathrm{Hu}$,u. Meningkatnya hasil belajar peserta didik salah satunya karena penggunaan model pembelajaran yang bervariasi dapat meningkatkan hasil belajar peserta didik sehingga pendidik tidak hanya monoton menerapkan satu model saja di dalam pembelajaran. Pendidik dituntut menerapkan banyak model ( multi method), karena pada hakikatnya penerapan model pembelajaran yang bervariasi dapat memberikan pengaruh positif terhadap motivasi dan hasil 
Penelitian terdahulu yang mendukung hasil penelitian ini antara lain penelitian yang dilakukan oleh Citra Yunita dan Khairul Amdani (2014) menunjukkan bahwa model kooperatif tipe STAD dapat meningkatkan aktivitas belajar peserta didik dengan rata-rata aktivitas kelas $71 \%$ dengan kategori baik. (2) Ni Made Sunilawati, Nyoman Dantes, dan I Made Candiasa dalam hasil penelitiannya menunjukkan bahwa: model pembelajaran kooperatif tipe STAD berdampak lebih baik secara signifikan terhadap hasil belajar matematika dibandingkan dengan konvensional.. (3) Asneli Lubis (2010) menyatakan bahwa ada pengaruh yang signifikan antara model pembelajaran kooperatif tipe STAD terhadap hasil belajar Fisika peserta didik pada materi pokok gerak lurus di kelas X SMA Swasta UISU T.P. 2010/2011 dan penelitian selanjutnya dilakukan oleh Fahruddin (2014) menyatakan bahwa ada pengaruh metode pembelajaran kooperatif tipe STAD, JIGSAW dan TGT terhadap hasil belajar kognitif ditinjau dari kemampuan akademik mahasiswa semester IV (empat) program studi pendidikan biologi STKIP BIMA dengan nilai $p<0,05$ dengan nilai rerata dari post-test STAD adalah 52,81 dibandingkan dengan pembelajaran kovensional adalah 52,54 yang berarti metode
STAD berpengaruh dari pada metode kovensional.

Dari seluruh pembahasan di atas dapat disimpulkan bahwa adanya pengaruh penerapan model pembelajaran kooperatif tipe STAD terhadap motivasi dan hasil belajar peserta didik, mengindikasikan bahwa adanya variasi model pembelajaran dapat mempengaruhi motivasi dan hasil belajar mata pelajaran peserta didik sehingga pendidik perlu menerapkan berbagai model pembelajaran lain yang dapat memberikan pengaruh positif terhadap motivasi dan hasil belajar mata pelajaran Biologi khususnya di SMA Negeri $1 \mathrm{Hu}$,u Kabupaten Dompu dan seluruh sekolah-sekolah yang berada di Indonesia pada umumnya.

\section{KESIMPULAN}

Berdasarkan hasil penelitian dapat disimpulkan bahwa terdapat pengaruh penerapan model pembelajaran kooperatif tipe STAD terhadap motivasi belajar dan hasil belajar mata pelajaran biologi SMA Negeri 1 $\mathrm{Hu}, \mathrm{u}$, dengan nilai t-hitung 27,0>t-tabel 1,674 .

\section{DAFTAR PUSTAKA}

Asneli, Lubis. Pengaruh Model Pembelajaran Kooperatif Tipe STAD Terhadap Hasil Belajar Fisika Siswa Pada Materi Pokok Gerak Lurus Di Kelas X SMA Swasta UISU Medan ", e-Journal Dikfis Pascasarjana Unimed 1 (2012). 
Citra, Yunita dan Khairul Amdani, (2014) Pengaruh Model Pembelajaran Kooperatif Tipe Student Teams Achievement Division (STAD) Dengan Metode Eksperimen Terhadap Hasil Belajar Siswa Pada Materi Listrik Dinamis Kelas X SMA Dharmawangsa Medan T.P 2012/2013", e-Journal Universitas Negeri Medan Vol. 2 (2014)

Fahruddin, 2014. Pengaruh Model Pembejaran Kooperatif Terhadap Hasil Belajar Kognitif Mahasiswa Semester IV STKIP BIMA Tahun 2014. Jurnal Euradio. Hniv. Brawijaya.2014. Diakses Tgl. 10/9-2019.

Hamalik. Oemar. 2008. Perencanaan Pengajaran Berdasarkan Pendekatan Sistem. Jakarta: Bumi Aksara.

Kartimi dkk,2014. Pengembangan Kurukulum Jurusan Tadris IPA Biologi IAIN Syekh Nurjati ciribon dalam mengantisipasi penerapan kurikulum 2013. http://journal.urnes.ac.id./nju/index.ph p/jpii. Cirebon: IAIN Syekh Nurjati Ciribon.

Ni Made Sunilawati, Nyoman Dantes, I Made Landiasa.(2011). Pengaruh Model Pembelajaran Kooperatif Tipe STAD Terhadap Hasil Belajar Matematika Ditinjau dari Kemampuan Numerik Siswa Kelas IV SD”, E-Jurnal Program Pascasarjana Universitas Pendidikan Ganesha 3, 2013.

Rahmat, Adi. 2010. Kajian Terhadap Metode Dan Pendekatan Pembelajaran Biologi Di Sma: Kesenjagan Dalam Pembelajaran Dikelas. Juenal pengajaran MIPA. Fakultas pendidikan biologi Universitas Pendidikan Indonesia.
Risdiyawati, Yania (2012). “ Implementasi Model Pembelajaran Kooperatif Tipe Student Teams Achievement Divisions ( STAD) Untuk Meningkatkan Motivasi dan Hasil Belajar Akuntansi Siswa Kelas XI IPS 4 SMA Negeri 1 Imogiri Tahun Ajaran 2011/2012", Skripsi. Yogyakarta: UNY Press, 2012

Slavin, Robert E. (2005). Cooperatif learning. London: allymand Bacon

Sudarisman, Suciati. (2015). Memahami Hakikat dan Karakteristik Pembelajaran Biologi dalam Upaya Menjawab Tantangan Abad 21 serta Optimalisasi Implementasi Kurukulum 2013. Jurnal florea. Program Studi Pendidikan Biologi, FKIP Universitas Sebelas Maret Sukarta.

Sumargi, S.A.K. Dkk(2013). Pengaruh Model Pembelajaran Kooperatif Tipe STAD Terhadap Motivasi Belajar dan Prestasi Belajar IPA Siswa Kelas VI SD Negeri 3 Bedulu Tahun Pelajaran 2013/2014", e-Journal Program Pascasarjana Universitas Pendidikan Ganesha Vol. 3 (2013)

Suraida. 2013. Pendidikan Berwawasan Lingkungan Dalam Pembelajaran Biologi. Jurnal Pendidikan edu-Bio

Trianto. 2010. Mendesain Model Pembelajaran Inovatif-progresif. Jakarta: Kencan.

Uno, H.B. 2007. Teori Motivasi dan Pengukurannya: Analisis dibidang Pendidikan. Jakarta: Bumi Aksara

Uno, Hamzah B. 2016. Teori motivasi dan pengukuran. Bumi Aksara. Jakarta 